Beskydy, 2016, 9 (1-2): 41-48

(C) Mendelova univerzita v Brně

ISSN: 1805-9538 (Online)

http://dx.doi.org/10.11118/beskyd201609010041

\title{
Comparison of the herb layer composition in stands of several tree species in the Louny region
}

\author{
Jiř́i Viewegh ${ }^{1,2}$, Stanislav Miltner², Karel Matějka ${ }^{3}$, Vilém Podrázský $^{2}$ \\ ${ }^{1}$ Štépánovice 52, CZ - 66602 p.Předklášteř́, Czech Republic: viewegh.jiri@seznam.cz \\ ${ }^{2}$ Czech University of Life Sciences Prague, Faculty of Forestry and Wood Sciences, Kamýcká 1176, CZ - 16521 \\ Praha 6-Suchdol, Czech Republic \\ ${ }^{3}$ IDS, Na Komořsku 2175/2a, CZ - 14300 Praha 4 - Komoŕany, Czech Republic
}

\begin{abstract}
Viewegh J., Miltner S., Matějka K., Podrázský V. 2016: Comparison of the herb layer composition in stands of several tree species in the Louny region - Beskydy, 9 (1-2): 41-48

Influence of introduced northern red oak stands (Quercus rubra L.) on herb understory with comparison with herb understory of autochthonous Sessile oak (Quercus petraea agg. L) and Scots pine (Pinus sylvestris L.) was observed in Louny region area on 14 plots. The analysis of the ground vegetation was performed using classical phytosociological methods. Significant changes were not determined in the site character, when comparing particular tree species stands, the differences consisted especially in the natural regeneration of tree species. Northern red oak showed a tendency of more fast penetration in the neighboring stands.
\end{abstract}

Key words: northern red oak, Quercus rubra, Sessile oak, Quercus petraea agg., Scots pine (Pinus sylvetsris), herb layers, comparison

\section{Introduction}

The northern red oak (Quercus rubra L.) has been planted in the Europe since 1691. Tree was very attractive in parks and ornamental collonades due to its marvellous colour in the autumn. Since 70's and 80's of the 20th century it has been speculating about its plantation in Czechoslovak forests due to hard dieback of autochthonous oak species (namely Sessile oak - Q. petraea agg. L.) by tracheomycosis (Burkovský 1985, Čapek et al. 1985, Gubka et Špišák 2010). Despite increased interest, this introduced tree species covers only $0.14 \%$ of the whole forest cover of Czechia to the year of 2010 (Miltner 2016). To make its wider use in forestry, it requests to know more about its influence on the habitat of the natural landscape. Podrázský
(1995) found that this introduced tree species could be the best for afforestation of reclamation areas due to fine litter and suitable humus form in such planted stands. Herb layer represents the clear reflection of the environmental conditions. It is often used as a bio-indication of the habitat (e.g. Kulich at al. 2002). Characteristic composition of the oak forest herb layer (including red oak stands, of course) in Eastern North America is described by McClenahen et Long (1995). Detailed description was made by Straigyté et al. (2012), including herb layer of red oak stands in Lithuania. This paper is the first step to show possible differences of herb layer in red oak stands (introduced tree species) and Sessile oak, Scots pine and European beech stands (natural tree species) in the Czech conditions. 


\section{Methods}

Chosen area of Louny district is characteristic by the lack of precipitation due to massive of Krušné hory Mts. (Ore Mts.) on the west. Plots were set up close Budyně nad Ohří and Peruc (Louny region). Climatic and soil conditions are described by Miltner (2016). Phytocoenological relevés were made in close canopy stands (2nd age class and older) of red oak and adjacent stands covered by autochthonous tree species (Tab. 1 + Appendix). Zlatník's scale has been used to describe species coverage (Zlatník 1978, p. 152). Taxonomical nomenclature was used according to Kubát (2002). Relevés were described in DBreleve program (Matějka 2013). Ellenberg's eco-values (Ellenberg et al. 1992) were computed for every relevéd plot as weighted averages of species coverage and tabulated values.

Relevés were classified by Ward (1963) method in PC-ORD system. Afterwards relevés were processed by CANOCO program (ter Braak et Šmilauer 2002), in which indirect gradient analysis DCA was used. This analysis has opened variability of the herb layer composition.

\section{Results}

Tab. 1 shows results of Ellenberg's eco-values. They could be influenced by the small amount of species in $\mathrm{E}_{1}$ layer, their low coverages and also by the lack of tabulated values of some species - either due to species indifference to corresponding factor or species is not tabulated (e.g. Quercus rubra). The highest dispersion shows factor of the light stand conditions $\left(\mathrm{I}_{\mathrm{L}}\right.$ $\langle 3.02 ; 7.98>$; i.e. shadow to semi-sunny habitats). Semi-sunny habitats apparently correspond with possible light penetration from the stand border, since the stands canopy were $80 \%$ at least (Appendix). Higher values of dispersion have proved to indices of soil reaction $\left(\mathrm{I}_{\mathrm{R}}<2.37\right.$; $5.00>$; i.e. acidophilous to slightly acidophilous habitats) and soil nitrogen content $\left(\mathrm{I}_{\mathrm{N}}<3.64\right.$; $6.00>$; i.e. poor to rich nitrogen content habitats). Nitrogen content is influenced by the litter amount and its type (see dominant tree layer Appendix) and also by an intensive agriculture activity in the close area, since this landscape has historically agricultural use (and the forests are often secondary there - Koláček 2009). According to humidity, habitats are slightly to fresh humid $\left(\mathrm{I}_{\mathrm{H}}<4.50 ; 5.33>\right)$. Indices of temperature $\left(\mathrm{I}_{\mathrm{T}}<4.99 ; 5.99>\right)$ and continentality
$\left(\mathrm{I}_{\mathrm{C}}<2.00 ; 3.94>\right)$ fit to localities - foothill zone and west of the Central Europe.

DCA ordination (Fig. 1) shows marked difference of the plot PE 4 from all others. A closer look at the input data (Appendix) indicates, that vegetation of this plot fits to a higher forest vegetation zone (FVZ) - beech. Second ordination axis divides plots according to nutrient content, from poor - plot BU 5 to nitrogen rich - plot BU 3.

Ward's dendrogram (Fig. 2) divides plots to 4 groups. Plots BU 1, BU 4, PE 1 and PE 2 belong to 1st group. Quercus rubra and Rubus fruticosus dominate on understory $\left(E_{1}\right)$ of these plots. Plots BU 2, BU 7, BU 5, BU 3, BU 6 and BU 8 cover 2nd group. These plots have not conspicuous dominance of some species in understory $\left(\mathrm{E}_{1}\right)$ and beyond plot BU 7, they have more species with low coverage in understory. Third group represents only one plot PE 4. As it is documented by DCA ordination (Fig. 1), this plot is different by its dominance of Fagus sylvatica in understory $\left(E_{1}\right)$ as the only plot. The last 4th group covers plots BU 9, BU 10 and PE 3. They are plots in whose understory $\left(E_{1}\right)$ Quercus petraea dominates, which are plots of compared autochthonous tree species.

\section{Discussion}

Chmura (2013) and Woziwoda et al. (2014) dedicate to influence of northern red oak on herb understory in south Poland territory, mainly of industrial Silesia forests, by more wide studies. Real natural forests almost don't exist there in this plane (or slightly hilly) area. Forests with autochthonous tree species are there only and also forests with these introduced species. Marozas et al. (2008) compared understory layer of northern red and common oaks forests (Quercus robur), but in such not industrial area yet. They all conclude, that herb understory in northern red oak stands is species poorer in comparison to autochthonous tree species stands with common oak. Their area is climatically different of ours and soils are more humid. Therefore, common oak was dominant tree species for comparison. As it is mentioned above, our plots were in rain shadow area (therefore sessile oak and Scots pine) and mostly nutrient poor (see forest type - Tab. 1). Results of our observation are rather different for this reason. Conditions of abiotic environment are reflected on all stands with 


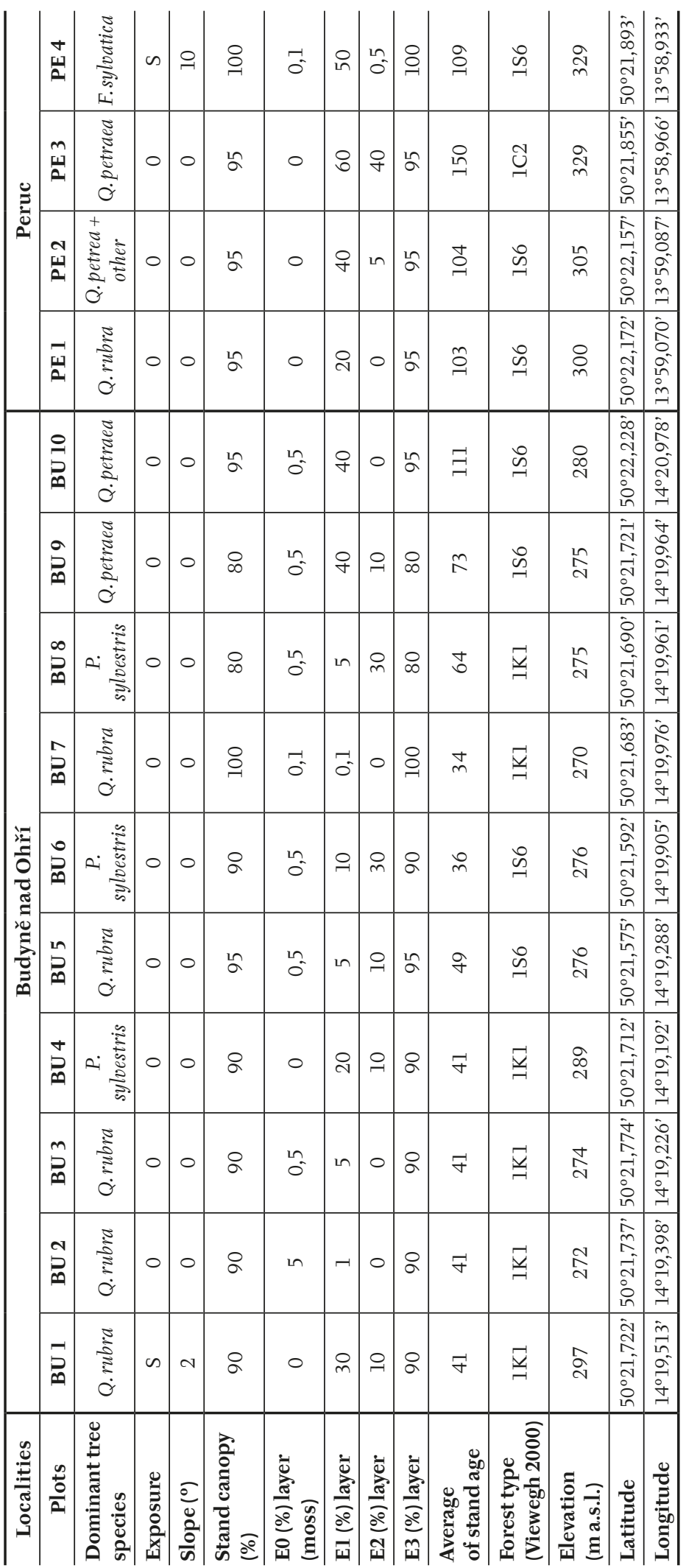


one exception. Both compared stands (northern red oak and adjacent sessile oak, event. Scots pine) also content northern red oak seedlings, but sessile oak seedlings are present on mother stands only and Scots pine seedlings lack (see Appendix). Absence of Scots pine seedlings could be explained by the fact, that pure stands of this tree species are not autochthonous here, which is declared by classification of forest types (Tab. 1). However, it should be emphasized, that our observation has been made in specific territory (rain shadow) and on 14 plots only. We have to extend our research to other territories, but it could be problem to find sufficient amount of plots, since the northern red oak total area is 6000 ha only in Czechia (Miltner 2016) and stands area of the third age class and older is considerably smaller (Kouba et Zahradník 2011).

\section{Conclusion}

Results of Ellenberg's eco-values (Tab. 2) have not proved differences among Quercus rubra and Q. petraea (Pinus sylvestris and Fagus sylvatica alternatively) stands in soil reaction and nitrogen content factors primarily. This shows, that the introduced Q. rubra does not appreciably influence soil chemistry. However, the further analyses (Ward's dendrogram and DCA ordination) show, that adult stands of the introduced tree species (Q. rubra) expanded more by its juvenile seedlings to adjacent compared stands of autochthonous Q.petraed and P. sylvestris. It could be symptom of its better germination and survivability in drier habitats.

\section{Acknowledgement}

This article was supported by the Czech Ministry of Agriculture Scientific Agency QJ1530298 - Optimizing the use of ameliorative and stabilizing tree species in the forests.

Thank to Mrs. A. Hitchen for English proofreading

\section{References}

Burkovský J., 1985, Viac pozornosti hromadnému hynutiu dubov $\mathrm{v}$ chraněných územiach. Pamiatky prirody, 1: 26-27

Čapek M a kol., 1985, Hromadné hynutie dubov na Slovensku. Príroda, Bratislava, 112 p.
Ellenberg H., Weber H.E., Düll R., Wirth V., Werner W., Paulißen D., 1992: Zeigewerte von Pflanzen in Mitteleuropa. Scripta Geobotanica XVIII, 2. verbesserte und erweiterte Auflage, Verlag Erich Goltze KG, 258 p.

Gubka K., Špišák J. (2010): Prirodzená obnova duba červeného (Q. rubra L.) na výskumných plochách Semerovce (LS Šahy). In: Knott R., Peňáz J., Vaněk P. (eds). Pěstování lesů v nižších vegetačních stupních. Brno, Mendel University in Brno: 30-34.

Chmura D. (2013): Impact of alien tree species Quercus rubra L. on understorey environment and flora: a study of the Silesian upland (Southern Poland). Polish Journal of Ecology 61: 431-442.

Koláček L.Y. (2009): České středohoří. Regina, Praha, 240 p.

Kouba J., Zahradník D.(2011): Produkce nejdůležitějších introdukovaných dřevin $\mathrm{V}$ ČR podle lesnické statistiky. In: Aktuality v pěstování méně častých dřevin v České republice 2011, Kostelec nad Černými lesy 21. listopadu 2011, ČZU, Praha, 52-66.

Kubát K., (ed.), 2002: Klíč ke květeně České republiky. Academia, Praha, 927 s.

Kulich M., Pigula T., Gutzerová N., Hrubý P. (2002): Bioindikace a biomonitoring. Jak poznat v jakém prostředí žijeme. SEVER, Horní Maršov, 75 s.

Marozas V., Straigyte L., Sepetiene J. (2008): Comparative analysis of allien red oak (Quercus rubra L.) and native common oak (Quercus robur L.) vegetation in Lithuania. Acta Biologica Universitatis Dauvgapiliensis 9, 1, 1-5.

Matějka K., (2013): Nápověda k programu DBreleve. Available at: http://www.infodatasys.cz/software/hlp_dbreleve/dbreleve. htm

McClenahen J.R., Long R.P. (1995): Variability in oak forest herb layer communities. In: Gottschalk, Kurt W.; Fosbroke, Sandra L. C., ed. Proceedings, 10th Central Hardwood Forest Conference; 1995 March 5-8; Morgantown, WV.: Gen. Tech. Rep. NE-197. Radnor, PA: U.S. Department of Agriculture, Forest Service, Northeastern Forest Experiment Station. 60-78

Miltner S. (2016): Pěstování dubu červeného (Quercus rubra L.) v podmínkách České republiky. Dizertační práce. FLD ČZU, Praha, 129 s. (deposited in SIC CULS Prague) 


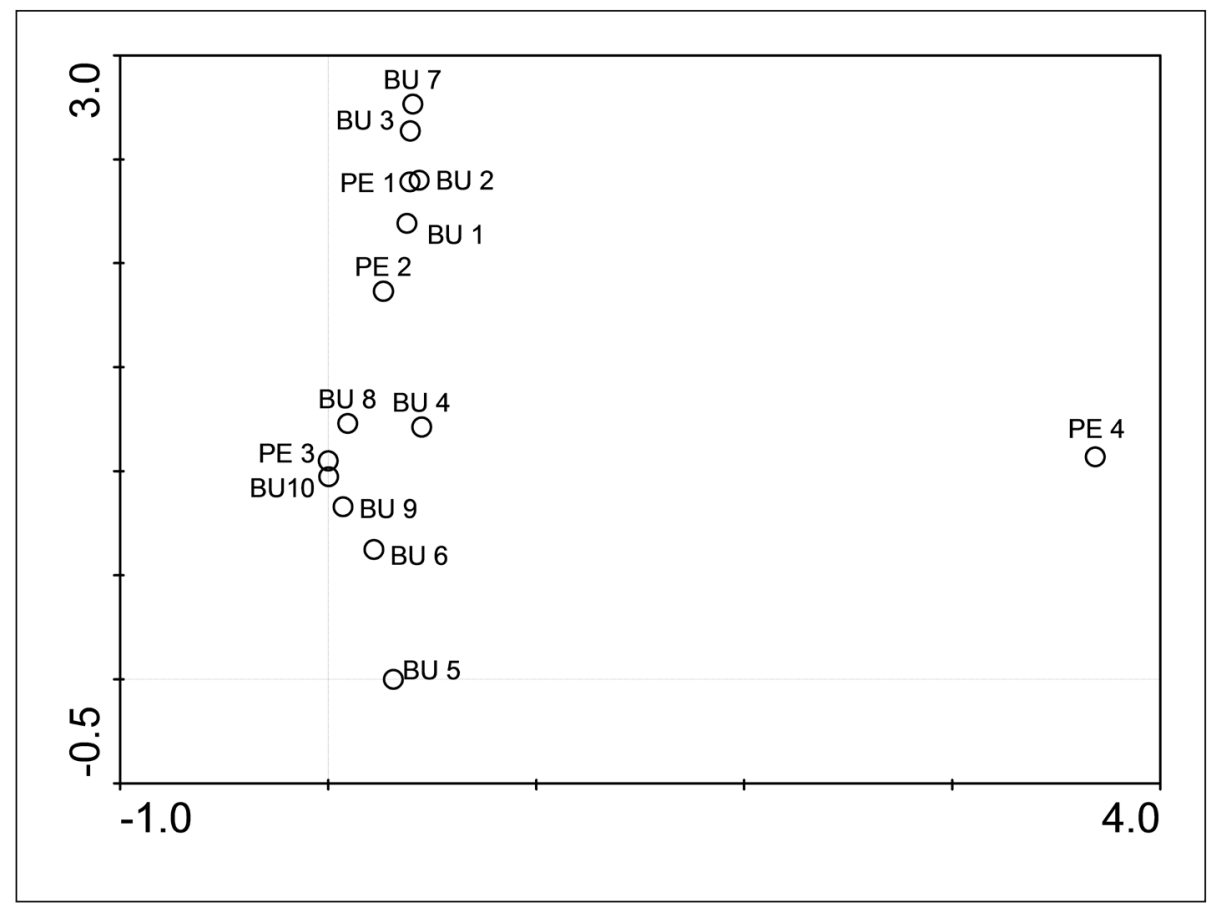

Fig. 1: DCA ordination of research plots

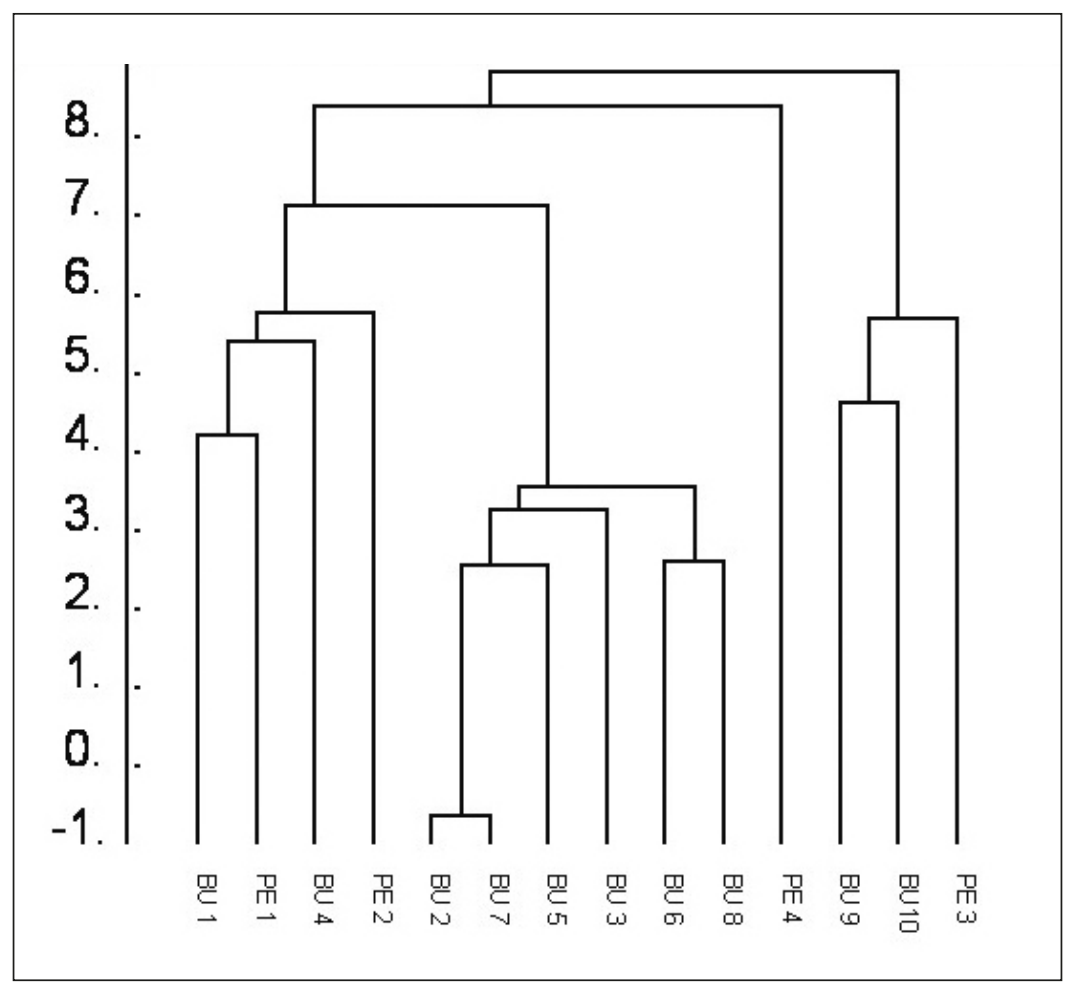

Fig. 2: Ward's dendrogram of research plots 
Podrázský, V., 1995, Vliv pěstebních opatření na akumulaci a pedochemické vlastnosti nadložního humusu a charakter svrchní vrstvy minerální půdy. Habilitační práce, LF ČZU, 165 s.

Straigyté L., Mazoras V., Žalkauskas R. (2012): Morphological traits of red oak (Quercus rubra L.) and ground vegetation in stands in different sites and regions of Lithuania. Baltic Forestry 18, 1, 91-99.

ter Braak C. J. F., Šmilauer P., 2002: CANOCO reference manual and CanoDraw for Windows user's guide: Software for canonical community ordination (version 4.5). Microcomputer Power, Ithaca (NY), $500 \mathrm{~s}$.

Ward J. H. (Jr.), 1963: Hierarchical Grouping to Optimize an Objective Function. Journal of the American Statistical Association 58, 236-244.

Viewegh J., 2003: Czech Forest (Site) Ecosystem Classification. Czech University of Life Sciences Prague. Praha, 170 s.

Available in: http://fld.czu.cz/docs/forestry_ classification.pdf

Woziwoda B., Kopeć D., Witkowski J. (2014): The negative impact of intentionally introduced Quercus rubra L. on a forest community. Acta Societatis Botanicorus Poloniae 83 (1): 39-49.

Zlatník A., 1978: Lesnická fytocenologie. SZN, Praha, 495 s 


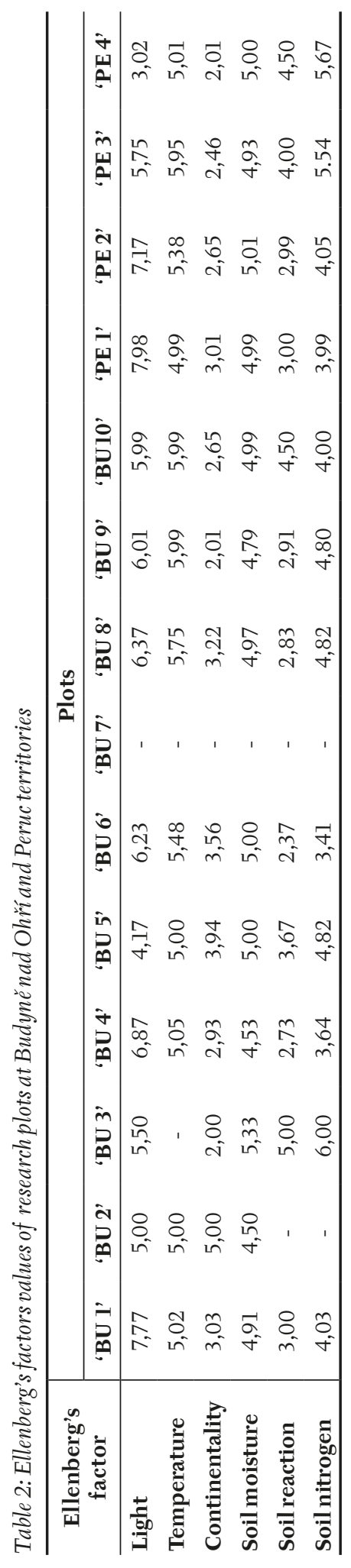


Appendix: Phytocoenological table of relevés

\begin{tabular}{|c|c|c|c|c|c|c|c|c|c|c|c|c|c|c|}
\hline Plots & $\begin{array}{c}\text { BU } \\
1\end{array}$ & $\begin{array}{c}\text { BU } \\
2\end{array}$ & $\begin{array}{c}\text { BU } \\
\mathbf{3}\end{array}$ & $\begin{array}{c}\text { BU } \\
4\end{array}$ & $\begin{array}{c}\text { BU } \\
5\end{array}$ & $\begin{array}{c}\text { BU } \\
6\end{array}$ & $\begin{array}{c}\text { BU } \\
7\end{array}$ & $\begin{array}{c}\text { BU } \\
8\end{array}$ & $\begin{array}{c}\text { BU } \\
\mathbf{9}\end{array}$ & $\begin{array}{c}\text { BU } \\
10\end{array}$ & $\begin{array}{c}\text { PE } \\
1\end{array}$ & $\begin{array}{c}\mathbf{P E} \\
2\end{array}$ & $\begin{array}{c}\mathbf{P E} \\
3\end{array}$ & $\begin{array}{c}\text { PE } \\
4 \\
\end{array}$ \\
\hline \multicolumn{15}{|l|}{ E3 (over 3 m) } \\
\hline Betula pendula & & & & & & & & 1 & & & & & & \\
\hline Fagus sylvatica & & & & & & & & & & & & & & +5 \\
\hline Larix decidua & & 1 & & & & & & & & & & 1 & & \\
\hline Pinus sylvestris & & & & +4 & & +5 & & +4 & & & & 1 & & \\
\hline Quercus rubra & +5 & +5 & +5 & & +5 & & +5 & & & & +5 & & & \\
\hline Quercus petraea & & 1 & & -2 & + & & & & -5 & +5 & & -5 & +5 & \\
\hline Tilia cordata & & & & & & & & & & & & + & & \\
\hline \multicolumn{15}{|l|}{ E2 (between 1 and $3 \mathrm{~m}$ ) } \\
\hline Acerpseudoplatanus & & & & & & & & & & & & & +3 & \\
\hline Aesculus pavia & & & & & & & & & & & & 1 & & \\
\hline Betula pendula & & & & & & +2 & & -3 & & & & & & \\
\hline Fagus sylvatica & -2 & & & & & & & & & & & & & + \\
\hline Quercus rubra & & & & & & & & 1 & & & & & & \\
\hline Sorbus aucuparia & & & & 1 & & & & & -2 & & & & + & \\
\hline Tilia cordata & & & & & -2 & & & & & & & & & \\
\hline \multicolumn{15}{|l|}{ E1 (up to $1 \mathrm{~m}$ ) } \\
\hline Acerpseudoplatanus & & & & & & & & & & & & + & -2 & \\
\hline Avenella flexuosa & & & & & & 1 & & $\mathrm{r}$ & $\mathrm{r}$ & & & + & & \\
\hline Betula pendula & & & & & & & & $\mathrm{r}$ & & & & & & \\
\hline Brachypodium sylvaticum & & & & & & & & & & & & & & $\mathrm{r}$ \\
\hline Calamagrostis epigeios & & & & & & $\mathrm{r}$ & & + & & & & & & \\
\hline Carexpairaei & & & & & & & & & & $\mathrm{r}$ & & & & \\
\hline Carexpilulifera & & & $\mathrm{r}$ & & $\mathrm{r}$ & & & & + & $\mathrm{r}$ & & & & \\
\hline Dryopteris dilatata & & & & & & $\mathrm{r}$ & & & & & & $\mathrm{r}$ & & $\mathrm{r}$ \\
\hline Fagus sylvatica & & $\mathrm{r}$ & & + & & & & & & $\mathrm{r}$ & & $\mathrm{r}$ & & +3 \\
\hline Fraxinus excelsior & & & & & & & & & & & & $\mathrm{r}$ & & \\
\hline Impatiens parviflora & + & & & & & & & & & & & & + & \\
\hline Larix decidua & & & & & & & & & & $\mathrm{r}$ & $\mathrm{r}$ & & & \\
\hline Melampyrum pratense & & & & & $\mathrm{r}$ & $\mathrm{r}$ & & & & & & & & \\
\hline Picea abies & & & & & & & & & & & $\mathrm{r}$ & $\mathrm{r}$ & & $\mathrm{r}$ \\
\hline Poanemoralis & & & & $\mathrm{r}$ & $\mathrm{r}$ & $\mathrm{r}$ & & & & + & & & 1 & \\
\hline Quercus petraea & & + & & + & & 1 & & 1 & +3 & +3 & & +2 & -4 & \\
\hline Quercus rubra & -2 & 1 & 1 & + & + & & $\mathrm{r}$ & + & & & -2 & -2 & & $\mathrm{r}$ \\
\hline Rubus fruticosusagg. & -3 & & & -2 & & 1 & & + & + & $\mathrm{r}$ & +2 & -3 & 1 & $\mathrm{r}$ \\
\hline Sorbus aucuparia & 1 & $\mathrm{r}$ & $\mathrm{r}$ & -2 & 1 & + & & $\mathrm{r}$ & -2 & & & & & \\
\hline Tilia cordata & & & & & 1 & + & & & & & & & & \\
\hline Urtica dioica & & & $\mathrm{r}$ & & & & & & & & & & & \\
\hline Vaccinium myrtillus & & & & & & 1 & & & & & & & & \\
\hline \multicolumn{15}{|l|}{ E0 (moss) } \\
\hline Dicranella hetromalla & & + & + & & + & & $\mathrm{r}$ & & & + & & & & \\
\hline Pleurozium schreberi & & & & & & + & & + & & $\mathrm{r}$ & & & & \\
\hline Polytrichum formosum & & 1 & & & & $\mathrm{r}$ & & $\mathrm{r}$ & + & & & & & $\mathrm{r}$ \\
\hline
\end{tabular}

